\title{
Dolomitic filler in self-compacting concrete: a review
}

\author{
Ahmed Abdalqader ${ }^{1,2}$, Mohammed Sonebi ${ }^{1 *}$ \\ ${ }^{1}$ School of Natural and Built Environment, Queen's University Belfast, Belfast, Northern Ireland, UK \\ ${ }^{2}$ Tracey Concrete Ltd, Northern Ireland, UK
}

Received: 07 July 2020 / Accepted: 14 November 2020 / Published online: 23 November 2020

This version contains an erratum published on 30.11.2020. The erratum consists of the added Acknowledgements section.

(c) The Author(s) 2020. This article is published with open access and licensed under a Creative Commons Attribution 4.0 International License.

\begin{abstract}
The utilization of fine powders as fillers in self-compacting concrete (SCC) application is widespread, particularly in Europe. The incorporation of these fillers to attain the self-compatibility properties of SCC seems to be cheaper than the use of chemical admixtures. Among the wide range of potential fillers, dolomitic powders, particularly generated as by-products from quarry's processing, are locally available and can be used to produce SCC. Few studies have shown that dolomitic powders can be incorporated in the SCC's mix design, resulting in acceptable fresh and hardened properties of SCC. The particle size distribution and fineness of the dolomitic powder as well as the level of addition are the key factors affecting those properties. The influence of the chemical nature of the dolomitic powder on the properties of SCC, particularly the durability (e.g. alkali-carbonate reaction), is yet to be investigated. Furthermore, more efforts are still required to investigate the use of dolomitic by-products in the production of SCC.
\end{abstract}

Keywords: Dolomite; Self-compacting concrete; Filler; Alkali-carbonate reaction

\section{Introduction}

Self-compacting concrete (SCC) is a special type of concrete which flows under its own weight without requiring external vibration for compaction. This is very useful in applications where normal vibrated concrete (VC) cannot be used such as narrow forms and reinforcement congested members. To attain the self-compacting property, it is required that the concrete have adequate viscosity, high deformability and high resistance to segregation. This is can be achieved by adding mineral admixtures (fillers) and/or viscosity modifying agents (VMAs). The former is the main practice in Europe and processed limestone powder is the most commonly used filler in the production of SCC. Moreover, the quarrying process of the production of mineral aggregate results in large amount of fine materials (quarry dust) as a by-product. These significant amounts of environmental wastes pose a real concern to manufacturers due to their impact on the environment, leading to economic consequences.

In fact, the constituents of VC and SCC are alike. Although fillers can be excluded in VC, they play a crucial role in SCC. The term filler could be defined differently according to the users and/or producers as wide variety of industries use fillers in their processes for economic, technical, and/or environmental reasons. The authors would define fillers in the context of SCC as:

Fine-grained inorganic materials other than cement, mostly less than $125 \mu \mathrm{m}$, that could be inert or nearly inert as well as pozzolanic or latent hydraulic and used in order to increase the powder content to improve the rheology of SCC and could affect the fresh and hardened properties of SCC by either physical, chemical and/or physiochemical mechanism.

The last definition implies that there is no limit on the raw materials, including wastes, that can be used to produce fillers for SCC application if they are free of deleterious minerals and have suitable fineness. However, the addition level is strongly dependent on the filler mineralogy and its particle size and shape [1].

Fillers can be used in a wide variety of market aside from the cement and concrete industries including cosmetics, pharmaceuticals, hygiene products, paper, food, adhesives, plastics, sealants and paints and, thus, filler production is a well-established technology worldwide [2]. Most fillers are produced by milling which can result in products above $5 \mu \mathrm{m}$ in size and the raw materials may require drying before processing. However, ultra-fine filler class can be produced but is perhaps a more challenging aspect of producing fillers on a large scale [3]. The global demand for fillers are predicted to reach about 75 million tonnes in 2024 [4]. The most important applications of fillers are the production and processing of paper, plastics, elastomers, paints and varnishes, as well as adhesives and sealants. The most commonly used filler on the global market is ground calcium carbonate (GCC), with a market share of $34 \%$ [5].

\footnotetext{
* Corresponding author: Mohammed Sonebi, Email: m.sonebi@qub.ac.uk
} 
It is worth mentioning that using fillers should be accompanied with occupational health considerations as some fillers such as crystalline silica (quartz, tridymite, and cristobalite) would impose health risk on workers [1]. Therefore, a risk assessment of using a specific filler should be conducted prior to use and all protection measures should be followed to minimise any risk on workers.

For the cement industry, the substitution of clinker by fillers, limestone powder for instance, proportionally reduces the thermal energy and $\mathrm{CO}_{2}$ emissions in cement production as fillers do not require calcination [1,6]. The interaction between fillers and cement can be on the physical level (filler effect), on the surface chemical level and/or on the chemical level [7]. The physical interaction means that the added fine particles only fill the intergranular pores between cement particles, thereby increasing the density and compactness of the concrete. The surface chemical interaction refers to the creation of nucleation sites by the added filler and thus accelerate the hydration process. The chemical interaction, which is less common in inert material and more common in pozzolanic and latent hydraulic powders, requires that the added fines react with the cement. For instance, some researchers found that limestone filler altered the hydration rate and reacted with cement to form calcium carbosilicate and carbo-aluminate hydrates $[5,6]$. However, the major effect of limestone filler is believed to be a physical dilution of the binder, thereby reducing the strength. This dilution effect can be effectively compensated by using low water/binder ratio and separate grinding of the filler [1]. Alexander et al found that the use of inert fine fillers improved the strength of concrete due to the development of a densified and homogenized the microstructure, particularly that of ITZ [8]. Similarly, improved strength and durability was reported as a consequence of the pore structure improvement when filler was used [7].

In SCC, the requirements to maintain the cohesion and avoid segregation necessitate the increase of the fine particles content compared to VC. If that is done solely by increasing the cement content, because cement is far finer than aggregates, issues with high heat of hydration and thermal shrinkage would be problematic. Therefore, the addition of fillers not only regulates the cement content but also improves the viscosity of the fluid mixture and its resistance to bleeding and segregation [9]. Additionally, replacing the cement content with a filler reduces the cost and the carbon footprint of the final product [10].

Fillers in SCC can be pozzolanic or non-pozzolanic and can be from natural, industrial or agricultural sources/by-products [11]. The most prevalently used pozzolanic fillers in SCC include coal fly ash, blast furnace slag, ground glass waste and silica fume. In addition, metakaolin, zeolite and rice husk ash have been also used, to less extent [12]. The most commonly used non-pozzolanic filler is limestone powder. However, other non-pozzolanic fillers have been utilized such as marble dust, ceramic waste powder [12], quarry dust [13-16], and olive residue biomass fly ash [17].

Aggregate pits and quarries can be a source of pollution and nuisances to the surrounding natural areas and to local residents as a result of the dust/fines created during processing [18]. The disposal of these waste poses a major economic and environmental threat to the aggregate industry. Therefore, utilizing these wastes in various applications has been studied by many researchers. The use of different types of quarry dusts depending on parent rocks have been investigated as fillers in SCC with numerous conclusions based on chemical and physical properties of the quarry dust as well as the level of addition [13,15,19-23].

As dolomite quarries are abundant, the potential of using the waste generated by the processing of these quarries in SCC is promising. However, there is a lack of comprehensive research or full utilisation of these fillers. Therefore, the present paper will review the use of dolomitic filler in the production of SCC in order to understand the prospective of locally available dolomitic fillers.

\section{Dolomite sources and production}

Dolomite $\left(\mathrm{CaMg}\left(\mathrm{CO}_{3}\right)_{2}\right)$ is a naturally sedimentary rock formed from the remains of billions of tiny shells and skeletons of microscopic animals or foraminifera in the presence of magnesium as a massive layer on the ancient rock [24]. Rocks containing only $10-50 \%$ of the mineral dolomite are called dolomitic [25]. Formation of dolomite can occur via two possible mechanisms: i) direct precipitation from solution to form primary dolomite, and ii) dolomitization process in which calcite undergoes dissolution supplying the $\mathrm{Ca}^{2+}$ ions followed by the precipitation of dolomite from a solution rich in $\mathrm{Mg}^{2+}$ ions [26]. Most, if not all, dolomite is a replacement of pre-existing limestone through the dolomitization process [25]. The dolomitization can be incomplete and therefore rocks termed 'dolomite' are usually a combination of dolomite, dolomitic limestone and limestone. Dolomite is an end-member mineral consisting of alternate layers of calcite $\mathrm{CaCO}_{3}$ and magnesite $\mathrm{MgCO}_{3}$ and theoretically, it crystallizes in the rhombohedral unit cell [27]. Divalent Fe substitution for $\mathrm{Mg}^{++}$in dolomite to form solid solutions toward ankerite $\left(\mathrm{CaFe}\left(\mathrm{CO}_{3}\right)_{2}\right)$ is not uncommon [28]. Dolomites bearing manganese, zinc, lead, strontium as well as cobalt and nickel also exist [27]. Dolomite reserves are ample worldwide, and their processing operations are considered low in cost, less toxic and environmentally friendly [26].

Dolomite decomposed at high temperatures in two consequence stages according to equations 1 and 2: at lower temperature $\left(\sim 750{ }^{\circ} \mathrm{C}\right.$ [29]), calcite and magnesium oxide form whereas calcite decomposes at higher temperature ( $\left.\sim 40{ }^{\circ} \mathrm{C}[29]\right)$ to form calcium oxide [30].

$$
\begin{array}{r}
\mathrm{CaMg}\left(\mathrm{CO}_{3}\right)_{2} \rightarrow \mathrm{CaCO}_{3}+\mathrm{MgO}+\mathrm{CO}_{2} \\
\mathrm{CaCO}_{3} \rightarrow \mathrm{CaO}+\mathrm{CO}_{2}
\end{array}
$$

Dolomite is extracted by surface quarrying using primarily drill and blast techniques but breaking by impact hammer can be used. Due to the discrepancies in chemistry and hardness of stone, the dolomite is selectively quarried at several distinct levels, known as 'benches'. Processing can be basically divided into crushing, screening, grading and storage prior to loading and transportation [25]. 
About $80 \%$ of the oil and gas reservoirs in North American carbonate rocks are in dolomites and up to $50 \%$ of the world's carbonate reservoirs are dolomites [31]. Permian dolomites are the main source of dolomite in the UK, but dolomite also occurs in some parts of the Carboniferous limestone sequence. However, in most areas the dolomitization is not sufficiently extensive, or of consistently high grade, to form a resource of industrial dolomite. Unlike limestone sources in the UK, dolomite resources mostly impure and may contain $0.2-0.25 \% \mathrm{Fe}_{2} \mathrm{O}_{3}$. In the UK, the total production of dolomite, in 2014, was 3.75 million tonnes, most of which was used in construction and the remaining in industrial/agricultural uses including as a filler [32].

\section{Properties and characterization of Dolomitic filler}

Pure dolomite has an $\mathrm{MgO}$ content of about $40 \%$. But most quarries would have a combination of dolomite, dolomitic limestone and limestone [25]. Dolomite is relatively soft and easily crushed to a fine powder. Dolomite when pure is colourless or pearly white but it sometimes has pink, green, gray, brown and black colors depending on the chemical composition and impurities. Dolomite has a Mohs hardness of 3.5 to 4 and is sometimes found in rhombohedral crystals with curved faces. The reaction between dolomite and cold, dilute hydrochloric acid is very week; however, if the acid is warm or if the dolomite is powdered, a much stronger acid reaction will be observed. Some physical properties of both limestone and dolomite are presented in Table 1.

Table 1. Some properties of Limestone and dolomite [33].

\begin{tabular}{|l|l|l|}
\hline Property & Limestone & Dolomite \\
\hline Molecular weight & 100.1 & 184.4 \\
\hline Specific gravity & 2.65 & 2.85 \\
\hline Moh's hardness & 3 & 3.5 \\
\hline $\begin{array}{l}\text { Decomposition } \\
\text { temperature }\left({ }^{\circ} \mathrm{C}\right)\end{array}$ & From 875 & From 400 \\
\hline Refractive index & 1.59 & 1.6 \\
\hline$\%$ brightness & $88-96$ & $88-95$ \\
\hline
\end{tabular}

\section{Uses of dolomite}

Dolomite has many industrial uses and can be used as raw dolomite or processed/calcined into a wide range of products (see Table 2). It is the raw material for a large variety of construction, agricultural, environmental, and industrial materials [34]. Large volumes of dolomite are used in construction as aggregate in concrete or asphalt [35] and it serves as a flux in metallurgy [25]. Dolomite can be decomposed to produce magnesia ( $\mathrm{MgO}$ ), which extensively used in manufacturing the most important products of the magnesium compound industry such as alloys, die casting, desulfurisation of iron and steel, refractories, pharmaceuticals, glass industry, fertilisers, etc. [3]. One interesting product is $\mathrm{MgO}$-based expansive agent added to cement/concrete to reduce their shrinkage [36-39]. Dolomite is effective also as a parent-sorbent for high temperature $\mathrm{CO}_{2}$ capture [40].
Table 2. Summary of uses of dolomite.

\begin{tabular}{|c|c|}
\hline Application & Purpose \\
\hline $\begin{array}{l}\text { Adhesives and } \\
\text { sealants }\end{array}$ & As a filler and as a viscosity control agent \\
\hline Construction & $\begin{array}{l}\text { As a filler for concrete, grout, asphalt and } \\
\text { roofing materials and as aggregate } \\
\text { It can be used as a dimension stone } \\
\text { It can be used as a ballast for railway } \\
\text { tracks }\end{array}$ \\
\hline $\begin{array}{l}\text { Magnesium and } \\
\text { magnesium } \\
\text { compounds }\end{array}$ & For production of magnesia \\
\hline $\begin{array}{l}\text { Environment } \\
\text { (desulphurization of } \\
\text { flue gas) }\end{array}$ & $\begin{array}{l}\text { As a natural alkali source and/or fire } \\
\text { suppressant } \\
\text { It can be used as beds in trickling filters } \\
\text { in sewage disposal plants }\end{array}$ \\
\hline $\begin{array}{l}\text { Fertilizer and } \\
\text { agricultural liming }\end{array}$ & $\begin{array}{l}\text { As a magnesium source and/or filler } \\
\text { And for rehabilitation of over-acidified } \\
\text { lands and waters } \\
\text { It can be used as a neutralising and } \\
\text { absorbent of organic wastes }\end{array}$ \\
\hline Ceramics & Kiln control \\
\hline $\begin{array}{l}\text { Paint and surface } \\
\text { coatings }\end{array}$ & $\begin{array}{l}\text { An aid to pigmentation, extenders } \\
\text { and/or finish aids }\end{array}$ \\
\hline Paper & $\begin{array}{l}\text { As a filler, coating pigments or acidity } \\
\text { control agents }\end{array}$ \\
\hline Plastic & $\begin{array}{l}\text { As a filler and to improve rheology, } \\
\text { mechanical properties and finish }\end{array}$ \\
\hline $\begin{array}{l}\text { Rubber and } \\
\text { elastomer }\end{array}$ & As a fillers or extenders \\
\hline Flux & As a flux in smelting metalliferous ores \\
\hline Glass & $\begin{array}{l}\text { As an important constituent of the batch } \\
(20-30 \%)\end{array}$ \\
\hline Refractory & As a basic refractory in making steel \\
\hline Rock dusting & $\begin{array}{l}\text { As a dust applied to the walls, roofs and } \\
\text { floors of coal mines to prevent or check } \\
\text { dust explosions }\end{array}$ \\
\hline
\end{tabular}

\section{Use of dolomitic filler/aggregate in Self- Compacting Concrete}

Research concerning using dolomite powder for production of SCC is very rare. The influence of dolomite powders, either commercially available or extracted from aggregate processing waste, on fresh and hardened properties of SCC is dependent on the physical properties of the filler and content, the replacement types and the mix proportions and constituents of SCC as can be seen in Table A1 in Supplemenatary Materials. For instance, the addition of dolomite powder to substitute slag in PC-slag systems, on one hand, did not change the hydration rate but led to a significant reduction of heat, particularly at $70 \%$ and $100 \%$ replacement level, while, on the other hand, the addition of dolomite powder to substitute fly ash or a mixture of fly ash and slag in PC-fly ash and PC-fly ash- slag systems, respectively, resulted in significant acceleration of the hydration rate and increased the total heat released [10]. This behavior was attributed to the physiochemical properties of the fillers compared to slag and fly ash [10]. It was revealed that replacing the cement in a dolomite-based SCC with fly ash and limestone would effectively reduce the total heat liberation, while the use of metakaolin had no effect on the total heat release of these mixes [41]. The particle size distribution of the dolomite is a key factor governing its effect on both fresh and hardened properties of cement-based composites [42]. Vaitkevičius et 
al [43] suggested that using up to $15-20 \%$ dolomite as a per cent of cement mass in the production of SCC would not compromise the mechanical strength and the selfcompatibility requirements. The incorporation of ground dolomite would increase the robustness of SCC [44]. The use of dolomitic filler in SCC was recommended in many standards and guidelines $[9,35,44,45]$. Detailed review of the effect of dolomite powders on fresh properties, hardened properties and durability of SCC is discussed in the following subsections.

\subsection{Fresh Properties}

Sahmenko et al. [46] used a dolomitic quarry by-products having a maximum size of $8 \mathrm{~mm}$ and containing $26 \%$ of fines less than $63 \mu \mathrm{m}$ to produce normal concrete (NC), highperformance self-compacting concrete (HPSCC) and Architectural concrete $(A C)$ with various $\mathrm{w} / \mathrm{c}$ ratios. The dolomite by-product represented $60 \%, 40 \%$ and $100 \%$ of the total aggregate in NC, HPSCC and AC, respectively. They reported that the HPSCC reached a slump flow of $590 \mathrm{~mm}$ by adding $1 \%$ SP and therefore it can be classified as SF1 according ENFRAC 2005 [46]. They explained that the angular shape of the dolomite by-product may cause the limited flowability. However, the obtained workability is acceptable as a SCC.

Rudžionis et al [47] examined the use of dolomite sifitings of $0 / 2$ fractions as a partial replacement to aggregate $(7-28 \%$ replacement levels) on the properties of SCC. The mixes were designed with a slump flow target between $620-650 \mathrm{~mm}$ and having a w/c of 0.55 and SP dosage of $1 \%$ of the cement content and by adding small quantities of viscosity modifying agent (stabilizer). They reported that the use of the dolomite siftings up to $14 \%$ increased the slump flow diameter without increasing the water content and beyond this percentage the slump flow diameter slightly decreased. The improvement of workability was explained by the effect of ellipsoid to sphere shape of the dispersive particles of dolomite siftings as examined by stereo microscope [47].

Martín et al [48] compared between a commercial dolomitic filler, not commonly used, and a reclaimed waste filler from bituminous mixtures. The dolomitic filler was a commercial fine-grained material from the crushing of marble from Macael (Almería) and XRD tests revealed that this filler is mainly dolomite with small quantities of calcite and quartz. The results of V-funnel and slump flow indicated that both fillers satisfy the requirements of SCC in regards of fresh and hardened properties measured with commercial dolomite filler mixes performed slightly better in all aspects. Other tests such as L-box test and slump flow test with J-ring were also carried out and showed satisfactory results. The fresh concrete density of the mixes containing commercial dolomite filler was about $2442 \mathrm{~kg} / \mathrm{m}^{3}$ while the air content was measured to be $1.4 \%$, which well below the $6 \%$ permissible level.

The incorporation of $7 \%$ and $14 \%$ of dolomite siftings of $0 / 2$ fractions significantly reduced the segregation index while increasing the percentage to $28 \%$ markedly increased the segregation index [47]. Heirman and Vandewalle [49] extensively studied the effect of various fillers, including 1 dolomite filler, 7 limestone fillers, 2 fly ashes and 2 silica fillers, on the workability of SCC. The source of the dolomite filler was not declared but the dolomite filler used was relatively coarser than all other fillers with a fineness of $236 \mathrm{~m}^{2} / \mathrm{kg}$ measured according to Blaine method described in EN 196-6 and $d_{50}$ of $37.1 \mu \mathrm{m}$. They found that the slump flow diameter and $T_{500}$ of concrete containing dolomite filler were $640 \mathrm{~mm}$ and 1s, respectively, which are appropriate according to the author's criteria. The range of those two parameters for all mixes were between 630 and $678 \mathrm{~mm}$ for slump flow and between 1 to $3 \mathrm{~s}$ for $T_{500}$. The time necessary for the concrete mix with dolomite filler to flow out of a V-funnel was $6 \mathrm{~s}$ (the acceptable range 5-15 s). In regards of the U-test filling height, SCC with dolomite filler had the highest filling ability of 329 $\mathrm{mm}$ (the acceptable level is higher than $300 \mathrm{~mm}$ ).

Nguyen and coworkers [10,50] explored the possibility of replacing supplementary cementitious materials with dolomite powder (DP) to produce self-compacting concretes and mortars (SCC/SCM). Their findings revealed that the addition of DP to PC-slag, PC-fly ash and PC-slag-fly ash mortars decreased the SP dosage required to reach the targete flowability measured by mini-slump and mini Vfunnel $[10,50]$. In contrast, Barbhuiya [51] reported that the addition of dolomite powder necessitates the increase of SP dosage in PC-FA-DP SCC to maintain the target flowability (550-650mm), except for the mix with 25\% DP. Based on the compressive strength of the mortars, Nguyen and coworkers [10] proceeded with the same systems with the addition of $30 \%$ dolomite powder as partial replacement of the pozzolanic materials in each system to produce SCC. The fresh properties of S-DP-30, S-FA-DP-30 and FA-DP-30 SCC were tested with various tests. Their findings indicated that all systems has acceptable fresh properties with S-FA-DP-30 SCC mix being marginally superior to other systems [10]. Similarly, another study found that, among all replacement levels, the addition of $25 \%$ of DP to substitiute fly ash would be suitable for SCC production [51]. The SCC mix with $100 \%$ DP as filler had a slump flow of $550 \mathrm{~mm}$, time increase of V-funnel after 5 minutes of $\sim 3.9 \mathrm{~s}$ and L-box ratio of $\sim 0.68 \mathrm{c}$ as shown in Table 3. Gabrijel et al [41] produced an SCC using commercial dolomite filler and aggregates with a slump flow of $732 \mathrm{~mm}$, a $\mathrm{T}_{500}$ slump flow of $2.08 \mathrm{~s}$, L-box ratio of 0.94 , segregation resistance of $5 \%$, a unit weight of $2499 \mathrm{~kg} / \mathrm{m}^{3}$ and an air content of $1.9 \%$. The physical and chemical properties of the filler and aggregates used were reported elsewhere [52].

Table 3. Summary of fresh properties of SCC incorporating dolomite powder (DP) and fly ash (FA) [51].

\begin{tabular}{|l|l|l|l|l|}
\hline Mix ID & $\begin{array}{l}\text { Dolomite } \\
\text { powder } \\
\text { percentage } \\
(\%)\end{array}$ & $\begin{array}{l}\text { Slump } \\
\text { flow } \\
(\mathrm{mm})\end{array}$ & $\begin{array}{l}\text { V-funnel } \\
\text { flow time } \\
(\mathrm{s})\end{array}$ & $\begin{array}{l}\text { L-box } \\
\text { ratio }\end{array}$ \\
\hline Mix 1 & 0 & $\sim 645$ & $\sim 5.9$ & $\sim 0.75$ \\
\hline Mix 2 & 25 & $\sim 630$ & $\sim 5.8$ & $\sim 0.78$ \\
\hline Mix 3 & 50 & $\sim 555$ & $\sim 5.5$ & $\sim 0.73$ \\
\hline Mix 4 & 75 & $\sim 555$ & $\sim 6.2$ & $\sim 0.74$ \\
\hline Mix 5 & 100 & $\sim 550$ & $\sim 7.8$ & $\sim 0.68$ \\
\hline
\end{tabular}


Billberg [53] studied the effect of 7 commercial dolomite fillers on the rheological properties, yield stress and viscosity, of two types of cement (labelled as Cement $S$ and D) using a fine mortar. Cement $S$ constitutes of $57 \% \mathrm{C}_{3} \mathrm{~S}, 13 \% \mathrm{C}_{2} \mathrm{~S}, 8 \%$ $\mathrm{C}_{3} \mathrm{~A}, 7 \% \mathrm{C}_{4} \mathrm{AF}, 3.4 \% \mathrm{SO}_{3}, 3.6 \% \mathrm{MgO}$ and $1.1 \%$ alkalis and has a blaine surfaces of $360 \mathrm{~m}^{2} / \mathrm{kg}$ while Cement $D$ constitutes of $53 \% \mathrm{C}_{3} \mathrm{~S}, 23 \% \mathrm{C}_{2} \mathrm{~S}, 1.6 \% \mathrm{C}_{3} \mathrm{~A}, 14 \% \mathrm{C}_{4} \mathrm{AF}, 2.1 \% \mathrm{SO}_{3}, 0.9 \% \mathrm{Mg0}$ and $0.47 \%$ alkalis and has a blaine surfaces of $300 \mathrm{~m}^{2} / \mathrm{kg}$. The fillers all has the same chemical composition but differs in the particle size distribuiton. He demonstrated that as the median particle increased to $40 \mu \mathrm{m}$ both the yield stress and viscosity decreased for both cements as shown in Fig. 1. This was explained by the increase of specific area required wetting by increasing the filler fineness, thereby increasing the shaear resistance of the suspension. The rheological values for the fillers with median particle size greater than $40 \mu \mathrm{m}$ were similar to those of $40 \mu \mathrm{m}$, indicating that no further decrease occurred.

Some researchers have used dolomitic aggregates to produce SCC. For instance, Cuenca et al. [17] examined the effect of olive residue biomass fly ash as a replacement to limestone filler in SCC made with dolomitic sand and gravel and concluded that this fly ash can be used to manufacture SCC. Similarly, Sadek et al. [54] produced a SCC with dolomitic coarse aggregate having a slump flow and V-funnel time between $675-765 \mathrm{~mm}$ and 7.6-10.1 s, respectively.
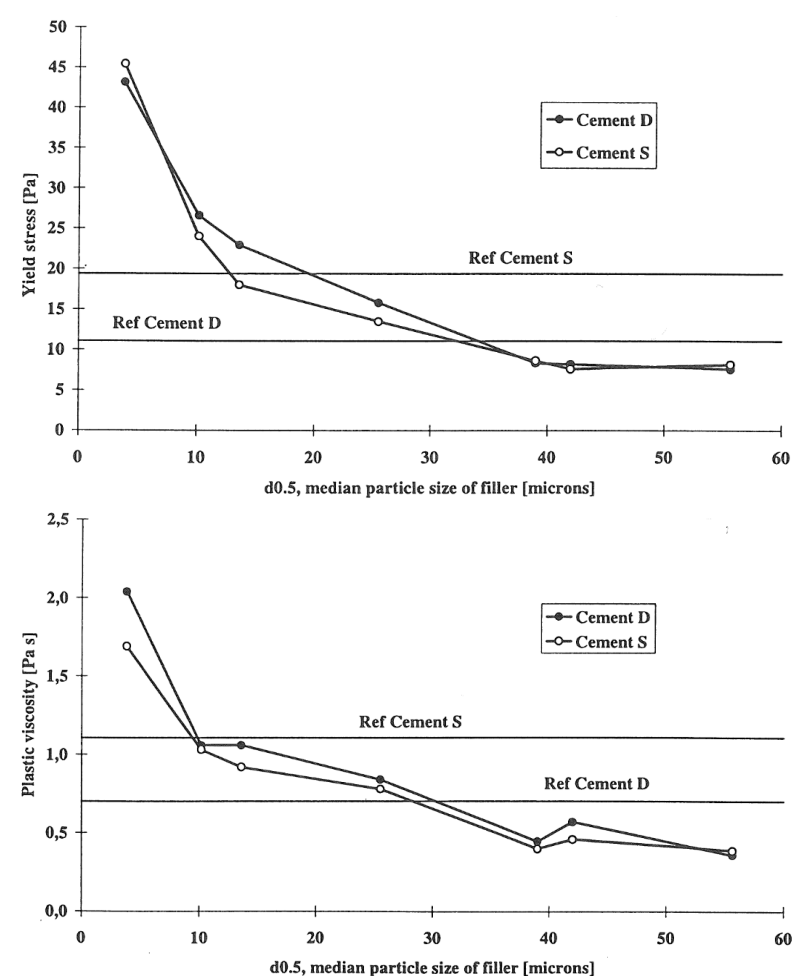

Figure 1. Relationship between median particle size of dolomitic filler and rheological properties: (top) Yield stress; (bottom) Plastic viscosity [53] (See Cement S and D properties above).

The data from the previous literature analysed in terms of the dolomite filler content as a percentage of the total powder content as can be seen in Fig. 2. Other relationships between the filler properties and fresh properties of SCC, e.g filler fineness and flow diameter, could not be established because of the lack of sufficient data. The figure shows the relationship between the dolomite filler percentage and the slump flow diameter. The dolomite filler percentage varies between $10 \%$ and $50 \%$ and the flow diameter changes between $550 \mathrm{~mm}$ and slightly above $800 \mathrm{~mm}$. The data implies a filler content up to $40 \%$ is likely to result in an acceptable flowability. However, as the data is not statistically representative, definite conclusion will require more testing and data.

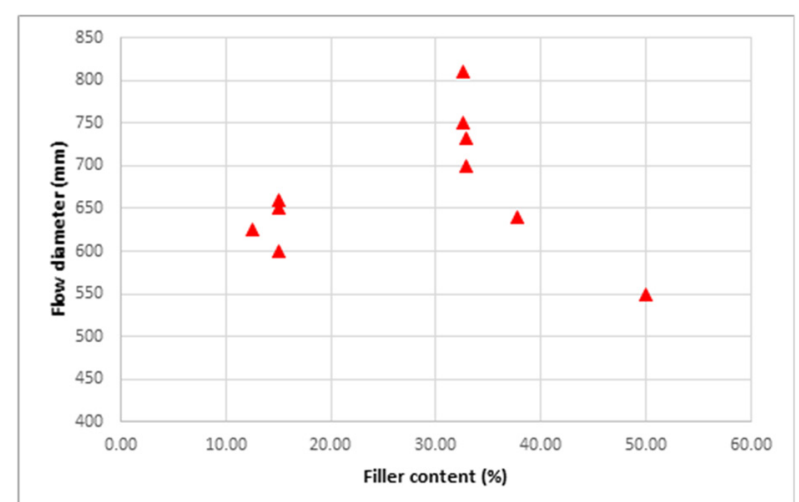

Figure 2. Analysis of flow diameter data from literature as a function of the dolomite filler content as a percentage of the total powder content.

\subsection{Hardened Properties}

The compressive strength of high-performance SCC studied by Sahmenko et al. [46] using $40 \%$ of dolomite by-products ( 0 $8 \mathrm{~mm}$ ) as a replacement to aggregate was higher than $70 \mathrm{MPa}$ at 28 days and higher than $80 \mathrm{MPa}$ at 56 days while the tensile splitting strength at 28 days reached 4.6 MPa. Similarly, Rudžionis et al [47] showed that the replacement of aggregate by dolomite siftings up to $14 \%$ increased the compressive strength and the modulus of elasticity. However, it was noticed that the strength was reduced as the dolomite siftings replacement level increased, Fig. 3. The authors attributed the improvement of strength up to $14 \%$ of replacement to the provision of $\mathrm{CaCO}_{3}$ by the dolomite siftings which partially react with aluminates compounds, making a new calcium carboaluminate complexes, thereby inosculating together make the cement stone stronger [47]. However, other researchers believed that the improvement of the strength can be due to the ettringite stabilization and the formation of carbonate AFm phases [55] or the formation of hydrotalcite [56]. SCC made of dolomitic aggregates and limestone filler can reach higher than $40 \mathrm{MPa}$ at 28 days [17]. Martín et al [48] obtained a $50 \mathrm{MPa}$ SCC with the use of 145 $\mathrm{kg} / \mathrm{m}^{3}$ commercial dolomite filler and $300 \mathrm{~kg} / \mathrm{m}^{3}$ cement using w/c of 0.55 and SP dosage of $1.8 \%$. In another study, the authors concluded that compressive strength development of SCC containing dolomite filler was analogue to those containing limestone fillers [49]. Moreover, they reported that SCC with dolomite filler developed higher strength than a reference vibrated concrete. The 1-day cube strength of the SCC mix was $10 \mathrm{MPa}$ while the reference mix had 1-day cube strength of 9.2 MPa and other SCC mixes with different fillers varied between 8.1 - 16.2 MPa. The 28-day and 90- $d$ cube 
strengths of dolomite filler mix were 59.7 MPa and 69.4 MPa, respectively. The long-term strength (i.e 90 -d strength) of the SCC mix with dolomite filler was slightly lower than the highest strength of 70.1 MPa [49]. Rukavina and co-workers $[41,52,57]$ obtained a 2-d cube strength of 57.3 MPa, 28-d cube strength of $81.1 \mathrm{MPa}$, a 365-d cube strength of 104.2 $\mathrm{MPa}$ and a 28-d static modulus of elasticity of $48 \mathrm{GPa}$ for dolomite-based SCC. The authors revealed that replacing the cement in their mix design with metakaolin increased the strength and modulus of elasticity with the increase of the metakaolin content, whereas replacing the cement with either fly ash or limestone lowered both values.

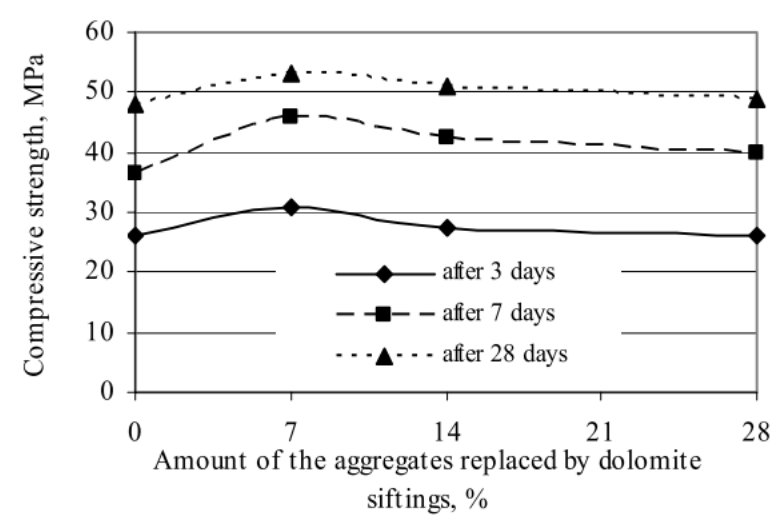

Figure 3. Development of concrete compressive strength as a function of the amount of replaced aggregates by dolomite siftings [47].

Soroka and Setter [58] investigated the effect of filler content and fineness on mortar strength. They used limestone, dolomite and basalt fillers with various fineness to replace 10$40 \%$ of PC. Their findings indicated that the limestone and the dolomite had similar effect on mortar strength, whose strength increased as both the fineness and filler content increased while the incorporation of basalt yielded even higher strengths which explained by the pozzolanic effect of Basalt used. At all ages, compressive strength of mortar containing these fillers were higher than the control mortar of pure PC. They attributed the effect of filler primarily to the acceleration of hydration occurred in the presence of the filler and partly to the densified mortar [58]. The addition of $30 \%$ dolomite powder to substitute slag and fly ash in PC-slag, PCfly ash and PC-slag-fly ash mortars improved the compressive strength $[10,50]$. Therefore, Nguyen et al. [10] examined the mechanical properties of PC-slag, PC-fly ash and PC-slag-fly ash SCCs using 30\% dolomite powder (DP) as a replacement to the pozzolanic material in each mix. The obtained compressive strength were in range of 35.4-46.4 MPa and 43.9-63.1 MPa at 7 and 28 days, respectively. The authors measured the strength efficieny of the cement in the presence of DP and concluded that addition of DP increased the strength efficiency to $0.15-0.20 \mathrm{MPa} /\left(\mathrm{kg} \mathrm{m}^{-3}\right)$ which is higher than that of $0.11-0.14 \mathrm{MPa} /\left(\mathrm{kg} \mathrm{m}^{-3}\right)$ normally used in practice on SCC design. It was also shown by means of ultrasonic pulse velocity that the SCC systems including 30\% DP had high quality to be used in concrete structures.
SCC mixes containing various contents (0-100\%) of DP filler as a replacement to fly ash, used as a filler with fixed PC content and $\mathrm{w} / \mathrm{b}$ ratio at $290 \mathrm{~kg} / \mathrm{m}^{3}$ and 0.38 , respectively, showed a slight loss in compressive strength with the addition of DP, particularly at 28 days. The compressive strength reported ranged between 33.22 to $37.91 \mathrm{MPa}$ as shown in Table 4. The loss in strength was attributed to the pozzolanic nature of fly ash, causing a reaction between glassy phase in the fly ash and calcium hydroxide generated from the hydration of Portland cement, thereby leading to the formation of additional C-S-H gel and higher strength [51]. This explanation, in our opinion, is somewhat confusing as the pozzolanic reaction would contribute to the strength gain at later ages (beyond 28 days) which is not provided in the study. Further, the variation in strength is relatively low and could not be considered statistically significant as the author did not provide error bars of the measured strength, particularly mixes with $100 \%$ DP gained marginally higher strength than mixes with $75 \%$ DP at 28 days. Therefore, more information on the purity and physical properties, particularly the particle size distribution and surface condition, of DP is required to understand its effect on the strength.

Table 4. Summary of hardened properties of SCC incorporating dolomite powder (DP) and fly ash (FA) [51].

\begin{tabular}{|c|c|c|c|c|}
\hline Mix ID & $\begin{array}{l}\text { Dolomite } \\
\text { powder } \\
\text { percentage } \\
(\%)\end{array}$ & $\begin{array}{l}\text { 3-d } \\
\text { strength } \\
(\mathrm{MPa})\end{array}$ & $\begin{array}{l}\text { 7-d } \\
\text { strength } \\
(\mathrm{MPa})\end{array}$ & $\begin{array}{l}28-\mathrm{d} \\
\text { strength } \\
(\mathrm{MPa})\end{array}$ \\
\hline Mix 1 & 0 & $\sim 18$ & $\sim 26$ & $\sim 38$ \\
\hline $\operatorname{Mix} 2$ & 25 & $\sim 17$ & $\sim 25$ & $\sim 35$ \\
\hline Mix 3 & 50 & $\sim 17$ & $\sim 22.5$ & $\sim 34$ \\
\hline Mix 4 & 75 & $\sim 16$ & $\sim 20.5$ & $\sim 32$ \\
\hline Mix 5 & 100 & $\sim 15$ & $\sim 21$ & $\sim 33$ \\
\hline
\end{tabular}

The compressive strength data from the previous literature analysed in terms of the dolomite filler content as a percentage of the total powder content as can be seen in Fig. 4. The 28-day strength largely varied between as low as 30 $\mathrm{MPa}$ to as high as $85 \mathrm{MPa}$.

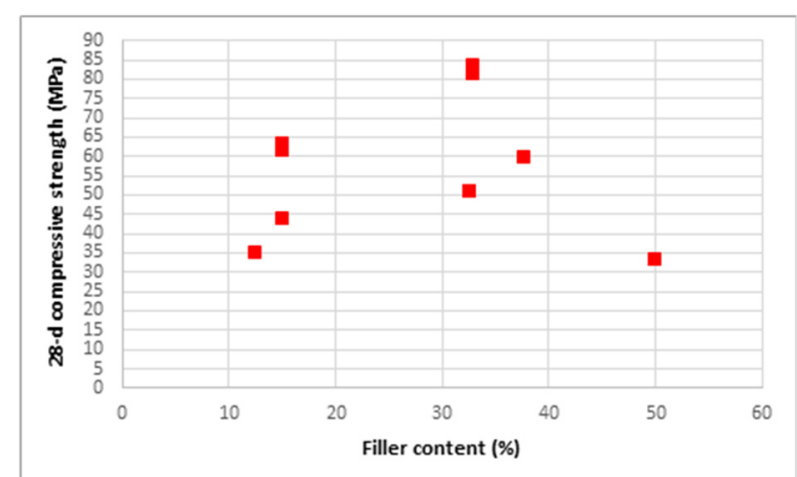

Figure 4. Analysis of 28-day compressive strength data from literature as a function of the dolomite filler content as a percentage of the total powder content.

The drying shrinkage of SCC samples incorporating dolomite siftings as partial replacement to sand was reported to be reduced compared to control samples at all replacement 
levels studied as can be seen in Fig. 5. However, the shrinkage increased as the dolomite siftings percentage increased. This behavior was explained by the measurement of open capillary pores average rate $(\lambda)$ which was found that the addition of $7 \%$ dolomite siftings decreased $\lambda$ from 2.29 to 1.96 while adding more dolomite siftings increased the rate. Moreover, the authors observed that the mass loss of mixes including up to $14 \%$ of dolomite siftings was $37 \%$ lower than the control mix with no dolomite siftings and observed that the tension strains of these mixes increased compared to the control, allowing the SCC to maintain its elastic properties under larger strains [47]. The behavior of drying shrinkage of SCC with various fillers including one dolomite filler were compared with normal vibrated concrete by Heirman and Vandewalle [49]. They showed that SCC developed higher shrinkage strains than the reference concrete and dolomite SCC mix had the second largest shrinkage strain of $\sim 550$ microstrain after 56 days.

The autogenous shrinkage of dolomite-based SSC were less than $0.20 \%$ [41]. It was found that replacing the cement of those dolomite-based SSC by metakaolin, fly ash and limestone resulted in increase in the autogenous shrinkage, unchanged in the autogenous shrinkage and reduction in autogenous shrinkage, respectively [41].

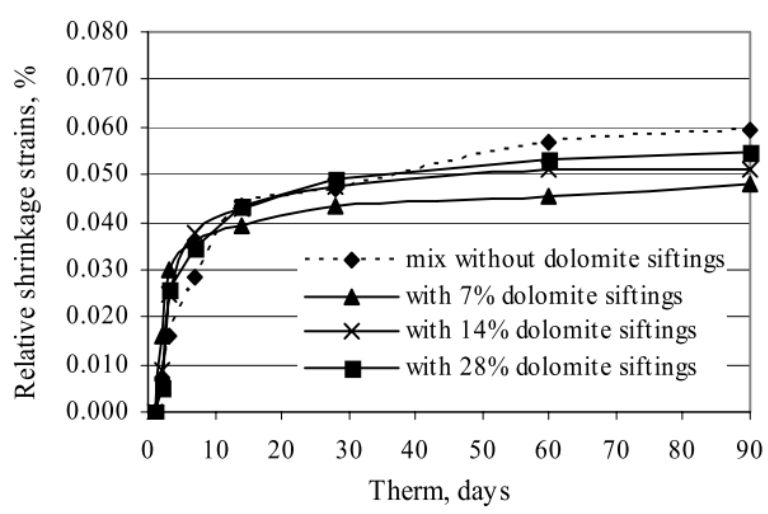

Figure 5. Development of concrete shrinkage strains as a function of the amount of replaced aggregates by dolomite siftings [47].

\subsection{Durability}

This section will discuss the available data on durability behavior of SCC containing dolomitic fillers. The porosity of SCC containing commercial dolomite filler was measured by Martín et al [48] and found to be about $12.26 \%$. A highperformance SCC $(w / C=0.56, w / b=0.175)$ comprising $40 \%$ dolomite by-product and $2 \%$ silica fume as replacement to aggregate exhibited a water penetration of just $15 \mathrm{~mm}$ when tested according to EN $12390-8$ by measuring the depth of water penetration under pressure [46] although the age of samples when tested was not declared. Rudžionis et al [47] studied the water absorption of SCC mixes incorporating 7$28 \%$ of dolomite siftings as partial replacement to sand and found that all mixes had lower water absorption than the control mix but increasing the amount of siftings increased the water absorption and capillary pore average index $\lambda$.

The durability of PC-slag, PC-fly ash and PC-slag-fly ash SCC incorporating $30 \%$ dolomite powder was assessed by the surface electrical resistivity (SER) using 4-point Wenner probe and found to range between 47.8-54.0 $\Omega . \mathrm{cm}$ at 28 days, implying low chloride ion permeability [10]. In a recent study, the frost resistance of high-performance SCC was performed by freezing and thawing of partially immersed samples in $3 \%$ $\mathrm{NaCl}$ solution. They measured the scaling of the samples and found that after 28 cycles their samples showed good frost resistance with a surface scaling between $150-250 \mathrm{~g} / \mathrm{m}^{2}$ [46]. They believed that surface scaling was caused by the destruction of separate weak dolomite particles. The $\mathrm{w} / \mathrm{c}$ ration in that study was high at 0.56 and the air content was $2 \%$.

Heirman and Vandewalle [49] studied the freeze-thaw resistance and freeze-thaw and de-icing salt resistance of SCC made with 12 different fillers including 1 dolomite filler. They found that all mixes including the reference mix and dolomite SCC mix exhibited high resistance to freeze-thaw exposure with unappreciable change on the longitudinal elastic modulus $\left(E_{d L}\right)$ values as the number of cycles increased. On the other hand, the behaviour after the exposure to freezethaw and de-icing salt was different. Similar to Sahmenko et al. [46], the test surface was subjected to a $3 \% \mathrm{NaCl}$ solution and 28 freezing and thawing cycles. After 7, 14 and 28 cycles, the amount of scaled material related to the test surface is measured, using a trickle of water to catch up the material in a paper filter, which was dried at $105^{\circ} \mathrm{C}$ afterwards. The authors noticed that the scaled materials of dolomite SCC mix up to 14 cycles were less than the reference vibrated concrete mix and comparable or lower than other SCC mixes. However, after 28 cycles all SCC mixes, except one fly ash SCC mix, had greater amount of scaled material than the reference mix [49]. It can be stated that dolomite SCC has a good freezethaw resistance in comparison with the reference concrete and other SCC, but high amount of scaled material is found when de-icing salts were added. Additionally, the results of freeze-thaw and de-icing salt resistance in terms of scaled materials after 28 cycles were $2710 \mathrm{~g} / \mathrm{m}^{2}$ as reported by Heirman and Vandewalle [49], which are much higher than the $150-250 \mathrm{~g} / \mathrm{m}^{2}$ values reported by Sahmenko et al. [46]. These discrepancies can be attributed to the difference in the mix designs of both studies. The dolomite SCC mix studied by Sahmenko et al. [46] is considered high performance SCC as it included silica fume and had higher quantities of dolomite filler than that studied by Heirman and Vandewalle [49]. Thus, it is expected that high performance SCC would perform better than SCC.

The freezing resistance of SCC mixes investigated by Rudžionis et al [47] including dolomite siftings showed better resistance than the control mixes at all levels of replacement. However, increasing the dolomite siftings led to a reduction in the freezing resistance criterion (ks) as a result of the increased and capillary pore average index $\lambda$ [47]. The authors did not give details on the procedure to measure the freezing resistance. The carbonation depth of SCC mixes incorporating commercial dolomite filler after the exposure to $1 \% \mathrm{CO}_{2}$ (in $65 \%$ relative humidity and $20^{\circ} \mathrm{C}$ ) found to be less than $30 \mathrm{~mm}$ at 28 months of treatment [48]. The behavior of dolomitebased SCC after exposure to high temperatures were 
examined [57]. They reported that after the exposure to 200 ${ }^{\circ} \mathrm{C}, 400{ }^{\circ} \mathrm{C}$ and $600^{\circ} \mathrm{C}$ the residual strength of the specimens measured was $\sim 80 \%, \sim 75 \%$ and $\sim 50 \%$, respectively. The study suggested that replacing part of the cement by up to $30 \%$ fly ash would be beneficial for high-temperature resistance from compressive strength perspective. Moreover, the residual modulus of elasticity was remarkably influenced by the temperature degree with values of $\sim 82 \%, 55 \%$ and $30 \%$ after the exposure to $200^{\circ} \mathrm{C}, 400^{\circ} \mathrm{C}$ and $600^{\circ} \mathrm{C}$, respectively. This indicates that Higher temperatures have more impact on the residual modulus of elasticity compared to the compressive strength.

When reviewing the dolomite effect on concrete properties, it is inevitable to discuss the alkali-carbonate reaction (ACR) or what so called, sometimes, dolomite-alkali reaction. ACR is an unusual and could have a potential deleterious effect on concrete durability although this is still a debatable topic and requires further investigations. The reactions that take place between carbonate rock and Portland cement paste have been investigated by several researchers [59-64]. No data available on the effect of using dolomite powder as a filler in SCC on this phenomenon. It is believed that dedolomitization can take place in certain conditions, which initiate and maintain the dolomite dissolution, leading to the formation of calcite and brucite in the presence of portlandite and forming cracks [65]. Higher temperatures and higher alkalinity content are believed to promote the dedolomitization mechanism $[59,60]$. However, that mechanism of dedolomitization is still not well understood and the dedolomitization reaction might not be responsible of the deterioration of concretes [61-63]. It is recommended, when using dolomitic aggregate or powder, that a program of testing on alkali-carbonate reaction should be carried out.

\section{Conclusion}

The intention of this paper has been to review the existing literature on the use of dolomitic filler in SCC in order to enhance the reader's theoretical and practical knowledge and facilitate the further development and application of dolomitic powders in SCC, and the realisation of its many advantages within modern construction technology. Unfortunately, very little research on dolomite effect are available either from field or from laboratory, apart from the reported studies discussed earlier. The available existing literature, however, has reported conflicting conclusions on the properties of SCC made with dolomitic fillers or aggregates. Nevertheless, the use of dolomitic fines would expand our choices when it comes to utilising dolomitic wastes from local quarrying activities. One common element that seems to exist among the studies reviewed that use of dolomitic fines or aggregates can produce good selfcompatibility properties of SCC in terms of flowability, passing ability and resistance to segregation. The investigations on mechanical properties of SCC containing dolomitic filler or aggregates suggest that there would be an optimum value of the level of dolomite addition to obtain maximised compressive strength. Durability aspects of SCC incorporating dolomitic fillers or aggregates have been far less investigated and no absolute conclusion can be drawn. Moreover, the alkali-carbonate reaction has not been investigated in any published work for SCC using dolomitic fillers. There are much more to research and investigate to gain a finer understanding of SCC's properties when dolomite sources are incorporating in the mix design as a filler or aggregate.

\section{Acknowledgements}

The fund and support from Innovate UK through the knowledge transfer partnership (KTP) program with Queen's University Belfast and Tracey Concrete Ltd is highly acknowledged.

\section{References}

[1] V.M. John, B.L. Damineli, M. Quattrone, R.G. Pileggi, Fillers in cementitious materials - Experience, recent advances and future potential. Cem Concr Res (2018) 114: 65-78. https://doi.org/10.1016/j.cemconres.2017.09.013

[2] G. Wypych, Handbook of Fillers, 4th ed., ChemTec Publishing, Toronto, 2016

[3] A. Tsirambides, Industrial applications of the dolomite from Potamia, Thassos Island, N. Aegean Sea, Greece. Mater Struct Constr (2001) 34: 110-113. https://doi.org/10.1617/13516

[4] Worldwide market for fillers forecast to reach 75 million tonnes/year in 2024. Addit Polym (2018) 11. https://doi.org/10.1016/S0306-3747(18)30096-4

[5] Market Study: Fillers, 2018. www.ceresana.com/en (accessed May 14, 2020).

[6] P.-C. Aitcin, S. Mindess, Sustainability of Concrete, Spon Press, 2011. https://doi.org/10.1201/9781482266696

[7] H. Moosberg-Bustnes, B. Lagerblad, E. Forssberg, The function of fillers in concrete. Mater Struct (2004) 37: 74-81. https://doi.org/10.1007/BF02486602

[8] M.G. Alexander, S. Mindess, Aggregate in Concrete, Taylor \& Francis, 2005.

[9] EFNARC, The European Guidelines for Self-Compacting Concrete. European Guidelines for Self Compacting Concrete (2005) 63. http://www.efnarc.org/pdf/SCCGuidelinesMay2005.pdf.

[10] H.A. Nguyen, T.P. Chang, J.Y. Shih, H. Suryadi Djayaprabha, Enhancement of low-cement self-compacting concrete with dolomite powder. Constr Build Mater (2018) 161: 539-546. https://doi.org/10.1016/j.conbuildmat.2017.11.148

[11] M. Tokkay, Cement and Concrete Mineral Admixtures, Taylor \& Francis Group, 2016. https://doi.org/10.1201/b20093

[12] R. Siddique, ed., Self-Compacting Concrete: Materials, Properties, and Applications, Woodhead Publishing, 2020.

[13] D.W.S. Ho, A.M.M. Sheinn, C.C. Ng, C.T. Tam, The use of quarry dust for SCC applications. Cem Concr Res (2002) 32: 505-511. https://doi.org/10.1016/S0008-8846(01)00726-8

[14] R.A. Schankoski, R. Pilar, L.R. Prudêncio, R.D. Ferron, Evaluation of fresh cement pastes containing quarry by-product powders. Constr Build Mater (2017) 133: 234-242. https://doi.org/10.1016/j.conbuildmat.2016.12.056

[15] R.A. Schankoski, R. Pilar, P.R. de Matos, L.R. Prudêncio, R.D. Ferron, Fresh and hardened properties of self-compacting concretes produced with diabase and gneiss quarry by-product powders as alternative fillers. Constr Build Mater (2019) 224: 659-670. https://doi.org/10.1016/i.conbuildmat.2019.07.095

[16] B. Mahalingam, P. Sreehari, S. Rajagopalan, S. Ramana Gopal, K. Mohammed Haneefa, Mechanical Characterization and Robustness of Self-compacting Concrete with Quarry Dust Waste and Class-F Fly Ash as Fillers. In: A.K. Lakshminarayanan, S. Idapalapati, M. Vasudevan (Eds.) Adv Mater Metall Lect Notes Mech Eng, Springer Singapore, Singapore, 2019, 365-373. https://doi.org/10.1007/978-981-13-1780-4 35

[17] J. Cuenca, J. Rodríguez, M. Martín-Morales, Z. Sánchez-Roldán, M. Zamorano, Effects of olive residue biomass fly ash as filler in selfcompacting concrete. Constr Build Mater (2013) 40: 702-709. https://doi.org/10.1016/j.conbuildmat.2012.09.101

[18] J. Fraser, R.A. McBride, The utility of aggregate processing fines in the rehabilitation of dolomite quarries. Land Degrad Dev (2000) 11: 1-17. https://doi.org/10.1002/(SICI)1099-145X(200001/02)11:1<1::AIDLDR352>3.3.CO;2-N 
[19] M.F. Granata, Pumice powder as filler of self-compacting concrete. Constr Build Mater (2015) 96" 581-590. https://doi.org/10.1016/j.conbuildmat.2015.08.040

[20] B. Felekoglu, Utilisation of high volumes of limestone quarry wastes in concrete industry (self-compacting concrete case). Resour Conserv Recycl (2007) 51: 770-791. https://doi.org/10.1016/j.resconrec.2006.12.004

[21] H.A.F. Dehwah, Mechanical properties of self-compacting concrete incorporating quarry dust powder, silica fume or fly ash. Constr Build Mater (2012) 26: 547-551. https://doi.org/10.1016/i.conbuildmat.2011.06.056

[22] A.S.E. Belaidi, L. Azzouz, E. Kadri, S. Kenai, Effect of natural pozzolana and marble powder on the properties of self-compacting concrete. Constr Build Mater (2012) 31: 251-257. https://doi.org/10.1016/i.conbuildmat.2011.12.109

[23] H.E. Elyamany, A.E.M. Abd Elmoaty, B. Mohamed, Effect of filler types on physical, mechanical and microstructure of self compacting concrete and Flow-able concrete. Alexandria Eng J (2014) 53: 295307. https://doi.org/10.1016/i.aej.2014.03.010

[24] J. Warren, Dolomite: occurrence, evolution and economically important associations. Earth-Science Rev (2000) 52: 1-81. https://doi.org/10.1016/S0012-8252(00)00022-2

[25] "Dolomite Fact Sheet," British Geological Survey, 2006.

[26] A. Banerjee, Estimation of dolomite formation: Dolomite precipitation and dolomitization. J Geol Soc India (2016) 87: 561-572. https://doi.org/10.1007/s12594-016-0430-9

[27] F.M. Hossain, B.Z. Dlugogorski, E.M. Kennedy, I. V Belova, G.E. Murch, First-principles study of the electronic, optical and bonding properties in dolomite, Comput. Mater. Sci. 50 (2011) 1037-1042. https://doi.org/10.1016/j.commatsci.2010.10.044

[28] L. Chai, A. Navrotsky, R.J. Reeder, Energetics of calcium-rich dolomite. Geochim Cosmochim Acta (1995) 59: 939-944. https://doi.org/10.1016/0016-7037(95)00011-9

[29] S. S Gunasekaran, G. Anbalagan, Thermal decomposition of natural dolomite. Bull Mater Sci (2007) 30: 339-344. https://doi.org/10.1016/S0144-2449(05)80171-X

[30] J.M. Valverde, A. Perejon, S. Medina, L.A. Perez-Maqueda, Thermal decomposition of dolomite under CO2: Insights from TGA and in situ XRD analysis. Phys Chem Chem Phys 17 (2015) 30162-30176. https://doi.org/10.1039/C5CP05596B

[31] D.H. Zenger, J.B. Dunham, R.L. Ethington, Concepts and Models of Dolomitization. Soc Econ Paleontol Mineral Spec Pub (1980) 28: 320. https://doi.org/10.2110/pec.80.28

[32] T. Bide, T.J. Brown, N. Idoine, J.M. Mankelow, United Kingdom minerals yearbook 2019, 2019. https://doi.org/10.1016/s03014207(97)90036-2

[33] "Calcium Carbonate: The world's most versatile mineral," British Calcium Carbonate Federation, 2017.

[34] J.E. Lamar, Uses of limeston and dolomite, 1961.

[35] J.D. Bliss, T.S. Hayes, and J. Greta Orris, USGS Fact Sheet: LimestoneA Crucial and Versatile Industrial Mineral Commodity, 2012.

[36] X. Lingling, D. Min, Dolomite used as raw material to produce MgObased expansive agent. Cem Concr Res (2005) 35: 1480-1485. https://doi.org/10.1016/i.cemconres.2004.09.026

[37] A.F. Abdalqader, F. Jin, A. Al-Tabbaa, Characterisation of reactive magnesia and sodium carbonate-activated fly ash/slag paste blends. Constr Build Mater (2015) 93: 506-513. https://doi.org/10.1016/j.conbuildmat.2015.06.015

[38] A.F. Abdalqader, F. Jin, A. Al-Tabbaa, Development of greener alkaliactivated cement: Utilisation of sodium carbonate for activating slag and fly ash mixtures. J Clean Prod (2016) 113: 66-75. https://doi.org/10.1016/j.jclepro.2015.12.010

[39] A. Abdalqader, F. Jin, A. Al-Tabbaa, Performance of magnesiamodified sodium carbonate-activated slag/fly ash concrete. Cem Concr Compos (2019) 103: 160-174. https://doi.org/10.1016/j.cemconcomp.2019.05.007

[40] S. Stendardo, P.U. Foscolo, Carbon dioxide capture with dolomite: A model for gas-solid reaction within the grains of a particulate sorbent. Chem Eng Sci (2009) 64: 2343-2352. https://doi.org/10.1016/j.ces.2009.02.009

[41] I. Gabrijel, M.J. Rukavina, D. Bjegović, Autogenous Deformation of Dolomite Based Self-Compacting Concretes With Different Mineral, in: RILEM Int. Work. Performance-Based Specif. Control Concr. Durab., Zagreb, Croatia, 2014, 507-514.

[42] A. Abdalqader, K. Wilson, N. Thornton, K. McHugh, S.E. Taylor, M. Sonebi, Preliminary investigation on the use of dolomitic quarry byproduct powders in grout for self-compacting concrete applications, in: K. Ruane, V. Jaksic (Eds.), Civ. Eng. Res. Irel. 2020, Cork Institute of Technology, Cork, 2020, 174-179.

[43] V. Vaitkevičius, A. Štuopys, E. Ivanauskas, Preconditions for the Application of Petrašiūnai Quarry Dolomite Screenings and Dolomite Powder in Conventional and Self-Compacting Concrete Mixes. Eng Struct Technol (2010) 2: 138-145 https://doi.org/10.3846/skt.2010.18

[44] D.A. Lange, "Self-Consolidating Concrete - A White Paper by Researchers at The Center of Advanced Cement Based Materials (ACBM)," 2007.

[45] D. Mitchell, K.H. Khayat, Self-Consolidating Concrete for Precast, Prestressed Concrete Bridge Elements, 2009. https://doi.org/10.17226/14188

[46] G. Sahmenko, A. Korjakins, D. Bajare, High-Performance Concrete Using Dolomite By-Products, in: K. Kovler, S. Zhutovsky, S. Spatari, O.M. Jensen (Eds.), Concr Durab Serv Life Plan, Springer International Publishing, Cham, 2020, 99-103. https://doi.org/10.1007/978-3-030-43332-1 20

[47] Ž. Rudžionis, E. Ivanauskas, M. Senkus, The Analysis of Secondary Raw Materials Usage in Self-Compacting Concrete Production. Mater Sci 11 (2005) 272-277.

[48] J. Martín, J. Rodríguez Montero, F. Moreno, J.L. Piqueras Sala, M.C. Rubio, Feasibility analysis of the reuse of waste filler of bituminous mixtures for the production of self-compacting concrete. Mater Des (2013) 46: 372-380. https://doi.org/10.1016/i.matdes.2012.10.009

[49] G. Heirman, L. Vandewalle, The influence of filler characteristics on the workability of self-compacting concrete. In: Pre-Proc 1st Int Symp Nanotechnol Constr (on CD), RSC Publishing; Cambridge, 2003.

[50] H.A. Nguyen, Enhancement of engineering properties of slag-cement based self-compacting mortar with dolomite powder. J. Build Eng (2019) 24: 100738. https://doi.org/10.1016/j.jobe.2019.100738

[51] S. Barbhuiya, Effects of fly ash and dolomite powder on the properties of self-compacting concrete. Constr Build Mater (2011) 25: 3301 3305. https://doi.org/10.1016/j.conbuildmat.2011.03.018

[52] M.J. Rukavina, I. Gabrijel, D. Bjegović, Modifications of dolomitebased self-compacting concrete properties using mineral additives, Tehnički vjesnik (2015) 22: 233-240. https://doi.org/10.17559/TV20140327212200.

[53] P. Billberg, Fine mortars rheology in mix design of SCC, in: Å. Skarendahl, Ö. Petersson (Eds.), PRO7 1st Int. RILEM Symp SelfCompacting Concr, RILEM Publications S.A.R.L., 1999, 47-58.

[54] D.M. Sadek, M.M. El-Attar, H.A. Ali, Reusing of marble and granite powders in self-compacting concrete for sustainable development. J Clean Prod (2016) 121: 19-32. https://doi.org/10.1016/j.jclepro.2016.02.044

[55] A. Machner, M. Zajac, M. Ben Haha, K.O. Kjellsen, M.R. Geiker, K. De Weerdt, Portland metakaolin cement containing dolomite or limestone - Similarities and differences in phase assemblage and compressive strength. Constr Build Mater (2017) 157: 214-225. https://doi.org/10.1016/i.conbuildmat.2017.09.056

[56] M. Zajac, S.K. Bremseth, M. Whitehead, M. Ben Haha, Effect of $\mathrm{CaMg}\left(\mathrm{CO}_{3}\right)_{2}$ on hydrate assemblages and mechanical properties of hydrated cement pastes at $40^{\circ} \mathrm{C}$ and $60^{\circ} \mathrm{C}$. Cem Concr Res (2014) 65 : 21-29. https://doi.org/10.1016/i.cemconres.2014.07.002

[57] M.J. Rukavina, D. Bjegovic, I. Gabrijel, Mechanical properties of selfcompacting concrete with different mineral aditives after high temperature exposure. In: Appl Struct Fire Eng 2013, 177-183. https://doi.org/10.1260/2040-2317.6.3.177

[58] I. Soroka, N. Setter, The effect of fillers on strength of cement mortars. Cem Concr Res (1977) 7: 449-456. https://doi.org/10.1016/0008-8846(77)90073-4

[59] E. García, P. Alfonso, M. Labrador, S. Galí, Dedolomitization in different alkaline media: Application to Portland cement paste. Cem Concr Res (2003) 33: 1443-1448. https://doi.org/10.1016/S0008-8846(03)00095-4

[60] S. Galí, C. Ayora, P. Alfonso, E. Tauler, M. Labrador, Kinetics of dolomite-portlandite reaction - Application to portland cement concrete. Cem Concr Res (2001) 31: 933-939. https://doi.org/10.1016/S0008-8846(01)00499-9

[61] T. Katayama, V. Jensen, C.A. Rogers, The enigma of the 'so-called' alkali-carbonate reaction. Proc Inst Civ Eng Constr Mater (2016) 169: 223-232. https://doi.org/10.1680/jcoma.15.00071

[62] T. Katayama, The so-called alkali-carbonate reaction (ACR) - Its mineralogical and geochemical details, with special reference to ASR. Cem Concr Res (2010) 40: 643-675. https://doi.org/10.1016/j.cemconres.2009.09.020

[63] T. Katayama, How to identify carbonate rock reactions in concrete. Mater Charact (2004) 53: 85-104. 
https://doi.org/10.1016/j.matchar.2004.07.002

[64] X. Zhang, F.P. Glasser, K.L. Scrivener, Reaction kinetics of dolomite and portlandite. Cem Concr Res (2014) 66: 11-18.

https://doi.org/10.1016/j.cemconres.2014.07.017

[65] E. García, P. Alfonso, E. Tauler, S. Galí, Surface alteration of dolomite in dedolomitization reaction in alkaline media. Cem Concr Res (2003) 33: 1449-1456. https://doi.org/10.1016/S0008-8846(03)00096-6 